\title{
Governing Indonesia's Secondary Education System: Challenges and Opportunities for Improvement in the Province of Yogyakarta
}

\author{
Astrid Meilasari-Sugiana ${ }^{1}$, Jumintono ${ }^{2}$ \\ ${ }^{1}$ Universitas Bakrie, Jakarta \\ ${ }^{2}$ Universitas Ahmad Dahlan, Yogyakarta \\ Correspondence: astrid.sugiana@bakrie.ac.id; masmintosragen@gmail.com
}

\begin{abstract}
This paper focuses on government policies for improving secondary education in decentralized Indonesia. The research combines policy evaluation in the field of education through mixed methods, namely the top down method measuring the effectiveness of Indonesia's policy reforms in numerical terms and the bottom up ethno-methodological approach incorporating soft system methodology for complementing policy evaluation. Data analysis was done by examining the distribution of narratives provided by the respondents and carrying out a thematic analysis in which emerging themes were used to produce a complex and coherent narrative of the discourse emerging from the case study site in Yogyakarta Province, Indonesia. The education system in modern Indonesia is marked by the tension between the centralized policy strategy of the Suharto period and the reactive strategy of Post-Suharto decentralization. During his current administration, President Joko Widodo promulgated education policies focusing on basic education reforms in five major areas, namely (i) facilitating the expansion of education facilities across Indonesia through the public and private sector (expansion of facilities and infrastructure in terms of quantity and quality), (ii) making basic education more affordable and accessible across regions and social-economic indicators (accessibility), (iii) improving the quality of educators, service and outputs in basic education (quality), (iv) increasing the relevance of basic education to the demands of tertiary education, the labor market and local economic development (relevance), and (v) good governance and accountability of Indonesia's basic education system (accountability and public responsiveness). In conjunction with the government and the market in education, indigenous social and political groups have played significant roles in developing the secondary education system in Indonesia. Moreover, these groups have also improved pupils' performance and pupils' learning outcomes by improving the extent and quality of the services they provide in comparison to those provided by public schools run by the government. Individualized services which cater to the needs, backgrounds and interests of the consumers have had profound impacts on enrollment, retention, motivation and pupils' character, knowledge, technical competence and competitiveness. This makes the education system more engaging, empowering and inclusive while taking into account its comprehensiveness. This also aids in promoting learning communities for complementing the
\end{abstract}




\section{GOVERNING INDONESIA’S SECONDARY EDUCATION SYSTEM}

government induced education system, for protecting children and for providing a holistic and integrated education services.

Keywords: social institutions; Indonesia's secondary education system; improvement 


\section{INTRODUCTION}

Indonesia, a highly diverse archipelagic nation with a population of roughly 240 million people, is a nation in demographic and social transition. The country is experiencing a rapid increase in population, with a projected population of 305.6 million in 2035. This is an increase of $28.6 \%$ from 237.6 million in 2010 . This signifies a rapid and expanding demand in education at all levels. Indonesia"s Human Development Index (HDI) in 2014 is 108 signifying medium level in human development, and the country joined the ASEAN Economic Community (AEC) in 2015. In this regard, Indonesia had to open its professional labor market to the ASEAN Community and increase its human resource competitiveness to close the gap with other ASEAN nations such as Malaysia and Singapore with relatively higher Human Development Index. Developing Indonesiaes human resources becomes critical for national security in the light of global and regional disparity, open competition and the volatility of the global labor market. Improving the system and quality of Indonesiaees education becomes one of the government"s priorities. The effectiveness of Indonesia $\mathrm{s}$ education system hinges on the roles of various stakeholders in complementing the government's roles. This includes the roles of parents, women, learning communities (e.g. women "es empowerment groups, community empowerment groups, youth empowerment groups, mosque groups, church groups, early childhood education/PAUD, etc), socio-political groups with strong religious ties (e.g. Muhammadiyah Foundation, Aisyiah Foundation, Jesuits, Kanisius Foundation) and the private sector with strong religious affiliations (e.g. Islamic boarding schools or Pesantren, Muhammadiyah schools, Kanisius Catholic schools and Penabur Christian schools).

A number of issues beset Indonesia ${ }^{e e}$ s secondary education system. These issues include disparity in access to education across geographical regions and socio-economic backgrounds, affordability of education across social-economic indicators, quality of education with regard to the teaching and learning process, teacher qualification and output competitiveness, relevance of education to the demands by tertiary education and the labor market, quality assurance in education and the accountability of Indonesiae s education system. Moreover, Indonesia ${ }^{\text {ee }}$ education system during President Joko Widodo ${ }^{\text {ee }}$ current administration is marked by tension between the centralized policy strategy of the de-concentration period and the reactive strategy of the decentralized era. President Joko Widodoes current decentralized public administration system relies on coordination mechanisms and provides the provincial and regency governments space to promulgate their own policies that are in line with national directives and the countryes objectives. As well, Indonesia is currently facing issues relating 
to indigenous uprisings, religious sectarian movements, political disintegration and social dissonance due to increasing regional and socio-economic disparity. Providing education facilities for the recognition, protection and empowerment of youth and children has become a form of Public Service Obligation (PSO), whereas providing secondary educational opportunities for combating illiteracy has become a form of Universal Service Obligation (USO). President Joko Widodo"es current administration also recognizes the complexity underlying the governance of the country ${ }^{\text {ee }}$ education system.

An innovation nationally ingrained within Joko Widodo $\mathrm{s}$ administration involves the acknowledgement of indigenous social and political groups, of their knowledge in providing educational services through the private sectors and of their knowledge management systems in educational services for promoting learning communities across Indonesia. In conjunction with the government and the market in education, indigenous social and political groups have played significant roles in developing the secondary education system in Indonesia. Moreover, these groups have also improved pupils ${ }^{e e}$ performance and pupilse learning outcomes by improving the extent and quality of the services they provide in comparison to those provided by public schools run by the government. Individualized services which cater to the needs, backgrounds and interests of the consumers have had profound impacts on enrollment, retention, motivation and pupilse character, knowledge, technical competence and competitiveness. Therefore, it is important to analyze and discuss the various indigenous social and political groups which have profound impacts on Indonesiaes secondary education system. The policy focus which Joko Widodo "s administration draws upon are innovative in nature and are expected to produce significant changes capable of being scaled up and integrated across government and geographical jurisdictions. An initiative promulgated by Joko Widodo"s administration includes mobilizing the various social components and their linkages for improving the system of education and its performance. This includes reviving and utilizing the kinship ties, tribal linkages, patron-client relations, familial lines, and religious and ethnic affiliations for improving the education system through the creation of learning communities beyond government initiatives. This makes the education system more engaging, empowering and inclusive while taking into account its comprehensiveness. The proposed research aims to identify the indigenous social and political groups which contribute to the development of the education system and the education performance in Indonesia through the creation of learning communities. 


\section{METHOD}

The research combines policy research and/or policy evaluation with research in the field of education through mixed methods, namely the top down method measuring the effectiveness of Indonesiaes policy reforms in numerical terms and the bottom up ethno-methodological approach incorporating soft system methodology for complementing policy evaluation. The overarching goal of this research is to analyze Indonesiae ${ }^{\text {ee }}$ education model, to highlight the limitations of the model and to design a new model which incorporates the complexity and dynamics found within the field sites. Another goal of the research is to evaluate and develop the effectiveness of the four major areas of education reforms in Indonesia. As part of the policy research/policy evaluation measures, the top down approach will be incorporated in testing the policy-practice linkages and its outputs and outcomes. Surveys, open ended questionnaires and short interviews are conducted to acquire data for the policy evaluation research.

Retrospectively, newly emerging findings which do not adhere to the positivistic policy edifice and template constructed by government departments also require a different set of approach for identification, assessment and incorporation into policy and practice. This is where the soft systems approach and the soft system methodology become relevant and pertinent. The soft systems approach incorporates assessments of the power constellations, power relations, communication patterns, reciprocity patterns, the social capital edifice and the social and political alignment processes which enable order, „consensuse ${ }^{\mathrm{e}}$, social cohesion and political commitment to emerge and endure for the improvement of Indonesia $\mathrm{s}$ education system through learning communities. As part of the soft system approach (e.g. the bottom up approach), the proposed research will incorporate situational analysis, participant observation, in depth interviews and life history analysis. The research incorporates purposive and stratified sampling for triangulation purposes. The soft systems approach is expected to yield new findings which are specific to the contexts and environment from which they emerged for continuous improvement and policy development. In turn, these new findings are expected to stimulate innovations in policy formulation and practice. These best practices will thus serve as lessons learned to be incorporated, implemented and integrated across scales through government policies, programs and technical guidelines.

As part of the policy research/policy evaluation measures, the top down approach is incorporated in testing the policy-practice linkages and its outputs. Surveys, open ended questionnaires and short interviews will be conducted to acquire data for the policy evaluation research. The research incorporates situational analysis, participant observation, in 


\section{GOVERNING INDONESIA’S SECONDARY EDUCATION SYSTEM}

depth interviews and life history analysis. The research incorporates purposive and stratified sampling for triangulation purposes. The research will incorporate 20 different public and private schools in Yogyakarta with a wide ranging background and reinforcements, including state schools, Islamic Boarding Schools, Muhammadiyah Islamic schools, Kanisius Catholic schools and Bopkri Christian Schools supported by Yogyakartaes social and political elites.

This research incorporated the mixed methods, namely quantitative research mixed with qualitative research. With regard to the quantitative approach, correlation measures will be incorporated to analyze the strengths of correlations between important variables relevant for system improvement. A qualitative research approach is also proposed for this study. The theoretical perspective most often associated with qualitative researchers is phenomenology (Bogdan \& Biklen, 2004). Following the phenomenological approach, researchers seek to understand meaning in events and in human interactions. Further, the context is important to the interpretation of data. This approach requires that the researcher "centers on the attempt to achieve a sense of the meaning that others give to their own situations" (Smith, 2005, p. 12). The data collected in a qualitative study includes more than words; attitudes, feelings, vocal and facial expressions, and other behaviors are also involved. The data which may consist of interview transcripts, field notes from observations, a wide variety of records and historical documents, and memoranda, are treated to rigorous ongoing analysis. Three processes are blended throughout the study: collection, coding, and analysis of data (Glaser \& Strauss, 1967): This approach encourages the kind of flexibility so important to the qualitative researcher who can change a line of inquiry and move in new directions, as more information and a better understanding of what are relevant data are acquired (Blumer, 1999). The research is limited to the Yogyakarta Special Province consisting of four regencies (Sleman Regency, Bantul Regency, Gunung Kidul Regency, Kulon Progo Regency and the Municipality of Yogyakarta). The research takes place from September 2015 until August 2016. 


\section{Secondary education policies in Indonesia and the Province of Yogyakarta}

The five major policy areas in the current government administration, along with their targeted outputs and performance indicators are as follow:

\begin{tabular}{|c|c|c|c|}
\hline No & Area & Key Performance Indicators & Targets \\
\hline 1 & $\begin{array}{l}\text { Improving } \\
\text { distribution } \\
\text { of secondary } \\
\text { education }\end{array}$ & $\begin{array}{l}\text { 1. Equality of opportunity: (a) current } \\
\text { government efforts to improve the } \\
\text { distribution of secondary education; (b) } \\
\text { baseline data/mapping the current gross } \\
\text { enrollment rates (GERs) in secondary } \\
\text { education across gender, social-economic } \\
\text { status, geographic locations;and (c) system } \\
\text { development to improve equality of } \\
\text { opportunity in secondary education } \\
\text { particularly for the poor and marginalized } \\
\text { people; } \\
\text { 2. Accessibility: (a) current government efforts } \\
\text { to improve accessibility of secondary } \\
\text { education; (b) baseline data/ mapping the } \\
\text { current accessibility in secondary education } \\
\text { across gender, social-economic status, } \\
\text { religions, and geographic locations; and (c) } \\
\text { system development to improve } \\
\text { accessibility insecondary education. } \\
\text { 3. Equity: (a) current government efforts to } \\
\text { improve equity in secondary education; (b) } \\
\text { baseline data/mapping the current equity } \\
\text { across individual differences in terms of } \\
\text { aptitudes, skills, interests, character traits } \\
\text { including disadvantages in secondary } \\
\text { education; (c) system development to } \\
\text { improve equity in secondary education } \\
\text { through creation of intervention systems } \\
\text { based on individual differences }\end{array}$ & $\begin{array}{l}\text { Education is well- } \\
\text { distributed, } \\
\text { accessible, and } \\
\text { equitable to all } \\
\text { people throughout } \\
\text { the country } \\
\text { regardless of their } \\
\text { gender, social- } \\
\text { economic status, } \\
\text { religions, and } \\
\text { geographic } \\
\text { locations } \\
\text { backgrounds }\end{array}$ \\
\hline 2 & $\begin{array}{l}\text { Improving } \\
\text { quality of } \\
\text { secondary } \\
\text { education }\end{array}$ & $\begin{array}{l}\text { 1. Current government efforts to improve } \\
\text { education quality in terms of providing } \\
\text { inputs, improving process, maximizing } \\
\text { outputs and outcomes. } \\
\text { 2. Baseline data/mapping the current quality in } \\
\text { secondary education in terms of the } \\
\text { adequacy of inputs required by secondary } \\
\text { education process such as updated } \\
\text { curriculum, provisions of teachers } \\
\text { (qualification, certification, competencies), } \\
\text { provision of well-equipped relevant and } \\
\text { updated school facilities and text books, } \\
\text { funding, school functions and organization } \\
\text { structures, etc.; process (teaching learning, }\end{array}$ & $\begin{array}{l}\text { High quality of } \\
\text { secondary } \\
\text { education } \\
\text { is available to all } \\
\text { people throughout } \\
\text { the country } \\
\text { without } \\
\text { discrimination }\end{array}$ \\
\hline
\end{tabular}

"The Improvement of Education Quality and Learning Process to Face the Recent Challenges" 


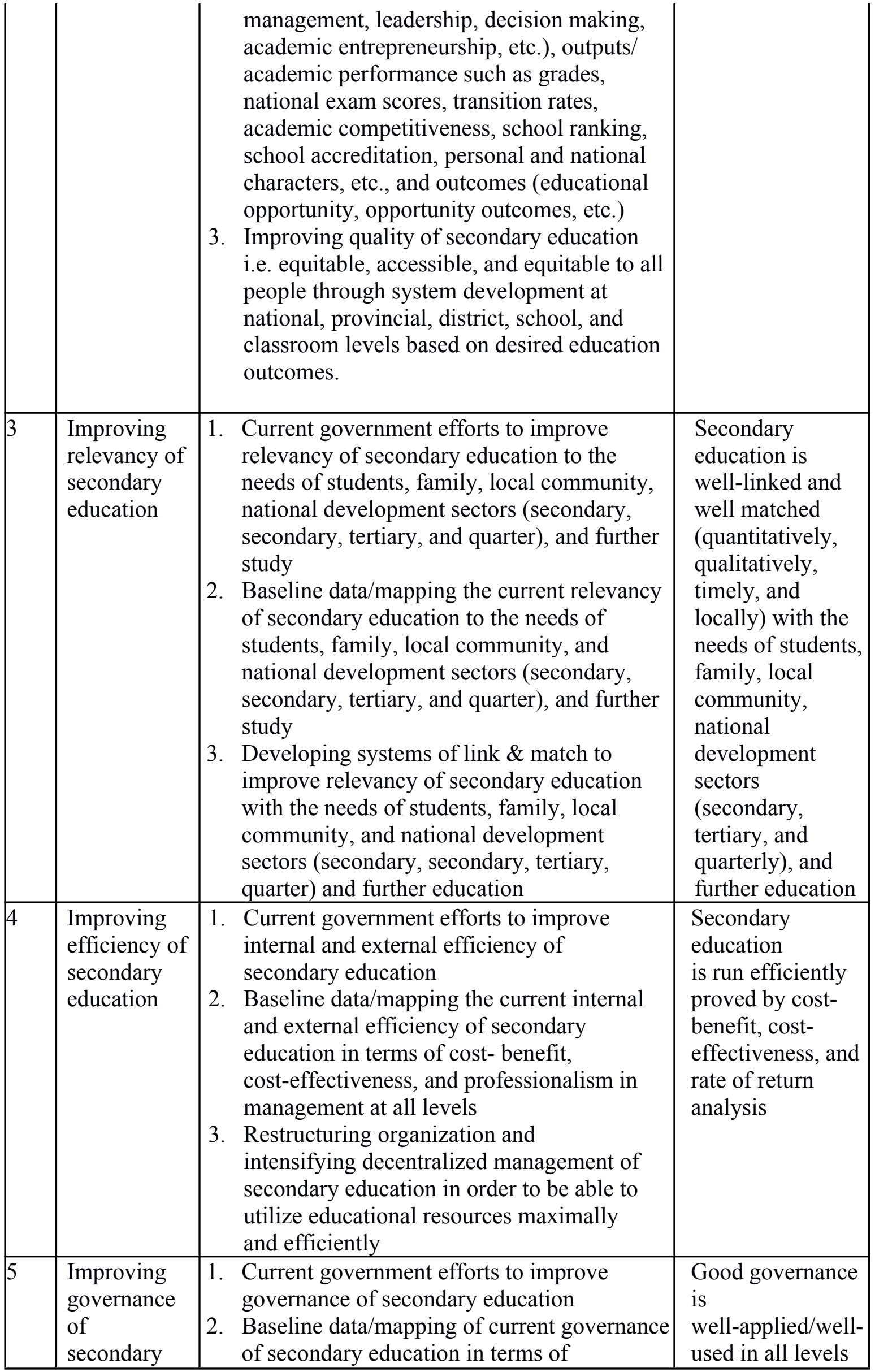




\begin{tabular}{|l|l|l|} 
education & $\begin{array}{l}\text { inclusiveness participation, transparency, and } \\
\text { accountability in planning, implementing, } \\
\text { and evaluating }\end{array}$ & $\begin{array}{l}\text { of } \\
\text { secondary } \\
\text { education } \\
\text { organizations } \\
\end{array}$ \\
& (Ministry, \\
& Province, \\
& District, \\
& Sub-district, \\
\hline
\end{tabular}

\section{Issues in Improving the Secondary Education System in Yogyakarta Province}

Issues in improving the secondary education system in Yogyakarta Province in particular and in Indonesia in general which stem from the interviews conducted by the researchers are illustrated below.

\section{Distribution of secondary education}

Indonesia"s petroleum export and Indonesiaes gains from the oil prices resulted in a striking increase in primary school enrollment in the 1980s and 1990s. Indonesia has achieved universal enrollment in primary school education in the early 1980 s and by the late 1980s almost all children were spending some time in primary school. Nonetheless in the 1990 s only $66 \%$ of pupils entering primary school actually graduated from grade six. This figure reached $81 \%$ in 2007 , improving greatly. Currently Indonesia has shifted attention to the second phase of basic education on the grounds that primary education is close to universal enrollment. Jobs in mid-level technical fields such as trades, administration and various kinds of services require junior secondary education. There is evidence that worker with more years of education deal better with change and secondary education increases people ${ }^{e e}$ s confidence in dealing with bureaucracies and diplomacies. Secondary education provides the insights, skills and competencies needed by workers in Indonesiae ${ }^{\text {ee }}$ rapidly changing economy. Senior secondary and tertiary education was formerly reserved for the selected few in Indonesia. Quantitative gains in education at the junior and senior secondary level have been very impressive. Indonesiaes Gross Enrollment Rates reached 50\% in the mid-1990s and Indonesia ${ }^{e e}$ s secondary school enrollment rate approached 80\% in 2010.

Nonetheless, issue of access to education and equity remains a big problem. There is no longer inequality of access by gender; nonetheless, there is issue of access and equity by socio-economic backgrounds and locations. Remote locations and rural areas are marked by poverty, low purchasing power and low access to educational facilities, thus location, socio-economic backgrounds and access to education are positively correlated. There is the need to lower the cost of education borne by low income families, to improve the 
accessibility and quality of the schools and schooling serving them and to subsidize bright students from low socio-economic backgrounds.

\section{Quality of secondary education}

Evidence suggests low quality of education in Indonesia. Problems include teacher absenteeism, emphasis on role learning, lack of cognitive abilities on behalf of the students, insufficient textbooks, poor infrastructure and building, lack of toilets and running water. Moreover, there has been little improvement in learning outcomes over the last decade. Children from poor families who manage to stay in school perform worse than children from richer families. Students whose parents have better education and higher status occupation tend to perform better than students whose parents have less education and a lower status occupation. Children of farmers, fishermen and blue collar workers tend to have examination results that are lower than children of civil servants, professionals and managers. The government ${ }^{\text {ee }} \mathrm{s}$ attempt to increase salaries of teachers by providing certification allowances and remote area allowances will have a big impact on government finances. The increase in expenditure in the education sector has no guarantee of success in raising the quality of education. Teachers hold secondary and tertiary jobs and often run their own businesses, making teacher absenteeism on the rise while demotivating teachers from improving themselves and eroding their professionalism, discipline and skills.

The quality of education system rests on three components: financial resources, policies and governments, and they determine the immediate outcomes in the form of teacher availability, teacher quality and performance and school infrastructure and management. The final outcome is the skills acquired by the students. Indonesia has more teachers than it needs. Teacher hiring continues to outpace increases in school enrolments and this led to an increased expenditures without commensurate impact on student learning outcomes. Political and other considerations at the local level also contribute to over hiring, along with elements of corruption and lack of transparency in the recruitment of teachers. It is suggested that a periodic recertification is required to provide incentives for teachers to upgrade their skills, discipline and professionalism. Quality and accountability of teachers are vital. Currently, dysfunctional teaching styles, high levels of absenteeism and limited commitment to the teaching role on the part of many teachers contribute to the low quality of secondary education. Obedience and loyalty characterizes the civil servant culture, thus there is a dwindling of the slightest inclination to innovate. As civil servants, rather than being evaluated on the quality of their work in the classroom, teachers are judged on their loyalty to the school principal and the district and regency/municipality education office. Thus there is 
little room for improvement and innovation. New and existing teachers should undergo orientation in order for them to assume leadership roles and increase the view of themselves as professionals. Evaluation system based on classroom performance, providing teachers with rigorous pre-service education and professional development and giving them the political space and the training to be able to act autonomously is very imperative. School management is also under fire. The formation of school committee for monitoring and pressuring towards better school management is imperative although school committees currently suffer from passivity and reluctance to intervene.

\section{Competence Based Curriculum and the relevance of secondary education.}

An issue inherent within the Indonesian education system is the issue of autonomy. The secondary education system requires some degree of autonomy and academic freedom in order to thrive and fulfill human resources needs within the autonomous regions. Nonetheless, the Government of Indonesia wants a tight control on its secondary education within the public, private or vocational education. The current debate in Indonesia focuses on research intensive education even though the overwhelming majority of secondary and tertiary education institutions are administered to focus on the needs of the local regions. The Competence Based Curriculum ( $\mathrm{CBC}$ ) has been introduced in Secondary Education, nonetheless, dynamic teaching has not been implemented and little effort has been made to ensure that teachers understand these changes and are able to translate them into appropriate activities. Therefore, classroom teachings remain traditional, dominated by memorization, repetition and conditioned learning, and intended changes in the curriculum have not been implemented at the school level. Changes and innovations within the culture of teaching is at the heart of the success of these policies. In-service workshops are pivotal to facilitating changes and innovations in implementing CBC. In addition, the institutional contexts in which teachers work must support and encourage them to dedicate themselves to the reform effort towards $\mathrm{CBC}$, student centered learning and critical thinking to avoid disconnections between policy and practice. The issue of adopting world class curriculum versus being locally relevant looms large for secondary education policy makers and local managers. Secondary schools, especially secondary vocational schools, are expected to supply skills to the local economy, to induce social transformations, to influence local policy making and to produce locally relevant technological innovations. Provisions that are required to achieve the above include, among others, instilling clear strategic vision at the regency/municipal and 
school management level, attracting motivated and talented staffs, and using resources efficiently to respond to local demands.

With regard to vocational schools, graduates of vocational schools have found themselves unemployed in recent years. The vocational schools need to link with industries and provide a curriculum that is tailored to specific labor market needs which may increase the employability of their graduates. Both the general and vocational tracks need to improve the balance of their curriculums with more specific and practical knowledge and strengthen their provincial of core academic skills. Moreover, the general and vocational schools need to strengthen their teaching of the academic and generic skills, to close the gap in math, literacy, English, critical thinking and behavioral and diplomacy skills. It is through improving the design and implementation of the specific skill component within the curriculum and by putting more emphasis on specific skills and improving links with industries that vocational schools can achieve the above. It is through concentrating on improving the ability to teach applied subjects such as business, economics, computing and English that the general schools can be made more relevant to changing needs.

\section{Efficiency of secondary education}

Law No 20/2003 on decentralization introduced school-based management and shifted the bulk of decision making on education spending and education management to local governments and schools for increased relevance, accountability and transparency purposes which are then monitored and evaluated by mechanisms between schools and the parents and the children they served through district level education boards and school committees. The law was supported by the 2005 introduction of a detailed set of guidelines on how school based management should be implemented and the School Operational Assistance or BOS Program, a nationwide grant program to support the implementation of school based management awarded on an equal per-student basis in which schools decide on its spending. The share of resources devoted to education differs greatly across districts and the ability of local governments to implement resources into improved outcomes also differs widely, whereas the relationship between education outcomes and levels of local government spending is weak.

The relationship between spending at the school level and education outcomes is complex and dynamic. Socio-economic status of the population, geographical locations and the size of the school aged population are the main elements which affect education outcomes. The research found that the less efficient districts have higher poverty rates. Moreover, the 
more efficient districts also tend to have more children of school age than the less efficient districts.

\section{Governance of secondary education}

The quality of governance also contributes to the relationship between spending and education outcomes. The research shows that local government quality has a positive correlation with education outcomes. Transparency and accountability had increased significantly in the Yogyakarta Province with the public having access to budget and monitoring sessions in local parliament, that financial reports were widely publicized and that mechanisms existed to allow wide participation in local education decision making. Issues which still beset the governance of secondary education in Yogyakarta include the management of information, and control systems and the efficiency of resource use. In addition, incentive systems for teachers, principals and school supervisors were frequently absent or undocumented. Moreover, stakeholder involvement in local government planning was very minimal.

Reliable and timely information was weak and this hampered the ability of local governments and schools to plan and allocate budget effectively. Students ${ }^{\text {ee }}$ test scores were often undocumented and therefore hampered planning with regard to education priorities, activities and resources. The research found that planning and budgeting allocations were based on the number of teachers and classrooms and not on students ${ }^{e e}$ needs, resulting in large gaps between budgeted and realized spending. Moreover, weak local governance provides additional incentives to hire more teachers than the standards require. Local level incentives to hire more teachers are compounded by intergovernmental transfer systems whereby districts with larger numbers of civil servants receive more from the transfer system. The BOS program gives schools a greater role in decision making and improvements in school based management does lead to a better student performance. Nonetheless, the research shows that parental and school committee participation remains the key to improving learning outcomes. Care should be taken for parents and school committee to be involved in decision making and budget allocation prior to budget approval.

\section{Institutions \& Opportunities to Improve Indonesia's Secondary Education System}

The main force behind intentional changes in Indonesiaee $\mathrm{s}$ education system over the past years has been a series of five-year national development plans formulated by the government to achieve the "just and prosperous society" to which the populace aspires. The first five year development plan (1969-1974) was to raise agricultural output, stimulate mining production, increase industries such as textile producers and build infrastructure for 
socio-economic progress. The educational component of the plan focused on: (1) providing enough educational facilities to accommodate the entire school-age population, particularly at the elementary level, (2) altering secondary-school enrollments from their present majority of students in general-academic curricula to a ratio that finds far more in vocational-training schools, particularly in agricultural institutions, (3) increasing the percentage of pupils who pass from primary to secondary education, particularly into vocational secondary schools, (4) reducing illiteracy in the adult population, (5) reducing the 50\% drop out rate in the elementary school, (6) increasing the corps of qualified teachers, and (7) improving administrative efficiency. The subsequent Second Five-Year National Development Plan dramatically increased funds for educational development by $666 \%$ over the First Plan. A further goal in the Second Plan was to improve the relevance and quality of education by publishing higher quality textbooks, expanding the in-service teacher-education program and improving the supervisory skills of the nation"es several thousand school inspectors.

The Third and Fourth Five Year Development Plan from 1979 until 1990 was designed to correct shortfalls in the Second Plan and extend the educational programs further in the general directions delineated for the Second Plan. The Fifth and Sixth Five Year Development Plan from 1990-2000 focused on the distribution of educational facilities across regions, on improving the quality, relevance and efficiency of the education system, on improving the governance of Indonesiaes education system and on increasing the number of enrollments in vocational schools. Indonesiaees education system during President Joko Widodoes current administration is marked by tension between the centralized policy strategy of the de-concentration period and the reactive strategy of the decentralized era. The de-concentration period during the Suharto administration endowed the national government authority to provide mandates to provincial and regency governments for top-down policy implementation, whereas President Joko Widodoees current decentralized public administration system relies on coordination mechanisms and provides the provincial and regency governments space to promulgate their own policies that are in line with national directives and the country ${ }^{\text {ee }}$ objectives. The above policies are incorporated as Indonesia is currently facing issues relating to indigenous uprisings, religious sectarian movements, political disintegration and social dissonance due to increasing geographical and socio-economic disparity. It is within this context that the current administration is incorporating social, religious and political groups into the education system and the education programs to create learning communities and complement government efforts in improving the education system. 


\section{Schooling as basis for unification and integration}

Three main streams have contributed to the nature of education in modern day Indonesia. First is the sort of informal training that children receive from the family and community. In the past as in the present, the core of what young people know about the nature of their world, the customs and language of their ethnic group, roles people play in life, and one occupation has been learned through direct participation in family and village life. The second stream is that of Islamic religious instruction, offered through the institutions of the langgar (small prayer house), pesantren (a non-graded school operated by Moslem scholars) and madrasah (Islamic institutions teaching a combination of western style schooling and Islamic teachings). The third stream was introduced by the European colonialists and is now the model adopted by the Indonesian government for creating secular schools. It is the institution typically known as a "school" in Western societies. It consists of a special building in which pupils are enrolled in grades that parallel their age levels. The curriculum is composed chiefly of such secular subjects as reading and writing the vernacular, history, geography, mathematics, science and foreign languages. Although the Islamic and Western secular schools still exist as two different systems in Indonesia - with the former under the Ministry of Religion and the later under the Ministry of Education and Culture - recent decades have found them becoming more alike.

\section{Growth of religious movements and religious schools within the education sector}

With the fourth largest education system in the world, Indonesia is listed to have 45,000 Islamic schools or Madrasahs by the Ministry of Religious Affairs in 2010. Many of the Madrasahs are set up by the local community and/or Islamic foundations with many of them being private schools in lieu of state sponsored alternatives. A majority of the Madrasahs have a lower income base, fewer resources and poorer facilities than state schools in Yogyakarta. The standard of education is also lower in comparison to state schools. They have disproportionately higher number of poor students and are targeted for girls in rural areas and urban areas. They deliver nine years of basic education, rivaling a total of 6 million students all over the country with 2.5 million in 14,000 Islamic junior secondary schools. They teach an additional $30 \%$ of religious Islamic subjects. Nonetheless, the system of education in state schools and in Madrasahs are different and do not overlap. Since the Madrasahs are under the supervision and direction of the Ministry of Religious Affairs, education management of Madrasah is not decentralized to the regency/municipality and district levels. This creates another layer of complexity since Madrasahs, whether be it private or public, experience barriers accessing funds from the regency, municipal and district 
governments since education funds are under the direction and control of the Ministry of Education and the Ministry of Home Affairs. Moreover, the National Accreditation Board for Schools and Madrasahs lack routine structural funding and is more a voluntary board, thus the provincial level accreditation boards with provincial funding play a more pivotal and important role. Nonetheless, the National Accreditation Board and the Provincial Accreditation Board implement somewhat different standards and guidelines, leading to duplications, fragmentations and disconnections. With regard to the authority for the management of private and public Madrasahs along with their funding disbursement, there is indeed overlapping authority, unclear directives and absent of coordination mechanisms between the ministries, the regency/municipal government, the district government and the schools themselves.

\section{Inclusive education and integrated services in education}

Indonesia is currently entering its third phase of the government ${ }^{\text {te }}$ Grand Design for Basic Education (2015-2019). An issue which looms large is the establishment of an integrated national education system. One of the obstacles in integrating Madrasah schools into the national education system is the presumption that Madrasah schools are substandard provider of education catering to the needs of the poor and the overly religious. Another is the limited awareness of the schools themselves and the limited awareness in the Ministry of Religious Affairs for the need to integrate. In order to integrate Madrasahs into the national education system, structural mechanisms should be put in place to encourage administrative cooperation and provide overarching authority and funding for the education system as a whole. Moreover, inter-ministerial cooperation is also important. It is imperative that the public and private Madrasahs be able to receive state funding through the education departments of regency/municipal and district governments.

\section{CONCLUSION AND RECOMMENDATIONS}

At the moment, Indonesia is optimistic with its state of education. There is an increase in the access of education, especially in secondary education across the country and across social-economic backgrounds. The national government is also committed in investing significant funding and resources in the education sector. As well, policies to improve the quality of education are also being implemented, monitored and evaluated. Nonetheless, the quality of Indonesian education is still quite low by international standards and the gap to access in education between the rich and the poor remains wide. Teacher quality and educational outcomes have not had significant impacts although there have been significant government funding allocation for the education sector. There is also a wide gap between the 


\section{GOVERNING INDONESIA'S SECONDARY EDUCATION SYSTEM}

demands by the local labor market and the supply of graduates from secondary and tertiary schools. In lieu of the above, the government needs to address the challenges by implementing practical policies aimed at improving the competence based curriculum through linkages with industries and third parties, strengthening teacherse ${ }^{\text {ee }}$ professionalism, skills and discipline, instituting coordination mechanisms for inclusive and integrated funding and administrative capacities and establishing sound governance mechanisms for transparency and accountability through monitoring and evaluation with parents, boards and the House of Representatives. It is imperative that the Government of Indonesia retain its authority and directives at the national level for inclusion and integration purposes without compromising the space given to regency and district governments to make locally accountable decisions in the management of schools and the allocation of resources. 


\section{REFERENCES}

Arfan Rauf. (2012). Kepemimpinan kolegial antara konsepsi dan realita. Di http://unismuh.ac.id/web/direktori/artikel/3106.html

Bass, B.M. and Avolio, B.J. (1994). Improving organizational effectiveness through transformational leadership. Sage, Thousand Oaks.

Bass, B.M. (1960), Leadership, psychology and organizational behavior, Harper and Brothers, New York.

Bush, T,. \& Coleman, M. (2006). Manajemen strategis kepemimpinan pendidikan (terj.) oleh. Fahrurrozi. Yogyakarta: IRCiSoD., Tony Bush and Marianne Coleman. 2000. Leadership and Strategic Management in Education. London: Paul Chapman Publishing Ltd.

Dardiri Ahmad. (2011). Pengembangan model kepemimpinan entrepreneur kepala sekolah dalam meningkatkan citra sekolah menengah kejuruan bertaraf internasional. Disertasi doktor tidak dipublikasikan, Yogyakarta : Program Pascasarjana Universitas Negeri Yogyakarta.

Gary Yuk.1. (2009). Leadership in organizations, Sixth Edition (Delhi : Dorling Kindersley, 2009) p.26.

Gregory E. Prussia, Joe S. Anderson, Charles C. Manz. (1998). Self-leadership and performance outcomes: the mediating influence of self-efficacy. Journal of Organizational Behavior, Vol. 19, No. 5 (Sep., 1998), pp. 523-538. Published by: John Wiley \& Sons. Stable URL: http://www.jstor.org/ stable/3100241.

Hater, J.J., \& Bass, B.M. (1988). Superiors' evaluations and subordinates' perceptions of transformational and transactional leadership. Journal of Applied Psychology, 73, 695-702.

Ibnu Sholeh. (2007). Pengertian kepemimpinan (leadership). http://myhad.blogspot.com/2007/04/pengertian-kepemimpinan-leadership.html

Jumintono. (2013). Pengembangan Model Kepemimpinan Kolegial Kepala Sekolah Dalam Meningkatkan Kualitas Lingkungan Akademik Sekolah Menengah Kejuruan . Disertasi doktor tidak dipublikasikan, Yogyakarta : Program Pascasarjana Universitas Negeri Yogyakarta.

Kardoyo. (2005). Pengaruh kepemimpinan kepala sekolah, pembiayaan dan peran komite sekolah terhadap kinerja sekolah (studi efektifitas di SMA se-kota Semarang (disertasi : http://digilip.upi.edu/pasca/ diakses 14 Nopember 2008) 
Laurie J. Mullins. (2005). Management and organisational behavior, 7thEdition, (Essex: Pearson Education Limited, 2005), p.282.

Mulyani. (2007). Pengaruh Kepemimpinan kepala sekolah, motivasi berprestasi dan budaya sekolah terhadap produktifitas SMP Negeri di kabupaten Brebes. (tesis PPS Unnes, tidak dipublikasikan)

Mustiningsih. (2005). Dinamika kelompok dalam kepemimpinan. Malang: Jurusan Administrasi Pendidikan Fakultas Ilmu Pendidikan Universitas Negeri Malang.

Newstrom, John W. \& Davis, Keith. (1993). Organizational behavior: human behavior at work. New York: McGraw-Hill

Northouse, P. (2010). Leadership theory and practice. Thousand Oaks, CA: Sage Publications.

P. Singh. (2005). Use of the collegial leadership model of emancipation to transform traditional management practices in secondary schools. Department of Postgraduate Studies \& Educational Research, Nelson Mandela Metropolitan University, P O Box 77000, Port Elizabeth, 6031 South Africa. South African Journal of Education $\begin{array}{llllll}\text { Copyright } & \text { C } & 2005 & \text { EASA } & \text { Vol } & 25(1)\end{array}$ www.ajol.info/index.php/saje/article/viewFile /24980/20680

Ritul Idha Djarwati. (2011). Kepemimpinan kepala sekolah dalam meningkatkan mutu sekolah. studi multisitus di SMKN 4 Malang dan SMKN 8 Malang. Tesis tidak dipublikasikan, Program Studi Manajemen Pendidikan, Program Pascasarjana Universitas Negeri Malang.

Robert N. Lussier and Christopher F. Achua. (2010). Leadership: theory, application, and skill development. 4th Edition (Mason, Ohio : South-Western Cengage Learning, 2010) p.6.

Sarros, J.C., \& Butchatsky, O. (1996). Leadership: australia's top CEOs - finding out what makes them the best. Sydney: HarperCollins Business.

Stogdill, R. M. (1974). Handbook of Leadership: A Survey of Theory and Research (New York: Free Press).

Susanto, A. B., (2012). Memilih pola kepemimpinan. Di http://www.jakartaconsulting. com/art-09-14.htm

Stephen P. Robbins. (2003). Essentials of organization behavior. 7th Edition (New Jersey: Pearson Education, Inc., 2003), p.130.

Syukra Alhamda, Rossi Sanusi. (2006). Persepsi Perilaku Kepemimpinan, Perilaku Sebagai Warga Organisasi Dan Kinerja Dosen Politeknik Kesehatan Padang Sumetara Barat. 
Working Paper Series No. 8 April 2006 Program Magister Kebijakan dan Manajemen Pelayanan Kesehatan,Universitas Gadjah Mada Yogyakarta.

UNESCO. (2007). Management of supervision staff: reforming school supervision for quality improvement. Paris: International Institute for Educational Planning.Wahjosumidjo. (2002). Kepemimpinan Kepala Sekolah. Jakarta: PT Raja Grafindo Persada.

Widodo, Joko. (2008). Kepemimpinan pendidikan transaksional dan trasformasional di SMK non teknik. Fakultas Ekonomi UNNES Semarang: Jurnal Pendidikan Ekonomi Vol 3 No.1 Februari, Tahun 2008.

Yammarino and Bass. (1990). Transformational leadership and multiple levels of analysis. Center for Leadership Studies and School of Management, State University of New York at Binghamton, Binghamton, New York 13901. http://hum.sagepub.com/content/43/10/975.short. 